\begin{tabular}{|l|l|}
\hline $\begin{array}{l}\text { 2. To: (Receiving Organization) } \\
\text { DISTRIBUTION }\end{array}$ & $\begin{array}{l}\text { 3. From: (Originating Organization) } \\
\text { RETRIEVAL SUPPORT OPERATIONS }\end{array}$ \\
\hline 5. Proj./Prog./Dept./Div.: & $\begin{array}{l}\text { 6. Design Authority/Design Agent/Cog. Engr.: } \\
\text { W-151/RPP }\end{array}$ \\
\hline
\end{tabular}

\section{Originator Remarks:}

FOR APPROVAL AND RELEASE

11. Receiver Remarks:

4. Related EDT No.:

N/A

7. Purchase Order No.

$\mathrm{N} / \mathrm{A}$

9. Equip./Component No.:

$\mathrm{N} / \mathrm{A}$

10. System/Bidg./Facility:

$\mathrm{N} / \mathrm{A}$

12. Major Assm. Dwg. No.:

$\mathrm{N} / \mathrm{A}$

13. Permit/Permit Application No.

$\mathrm{N} / \mathrm{A}$

14. Required Response Date:

$\mathrm{N} / \mathrm{A}$

\begin{tabular}{|l|l|}
\hline \multicolumn{2}{|l|}{15.} \\
\hline $\begin{array}{c}\text { (A) } \\
\text { tem } \\
\text { No. }\end{array}$ & (B) Document/Drawing No. \\
\hline 1 & RPP -6133 \\
\hline & \\
\hline & \\
\hline & \\
\hline & \\
\hline & \\
\hline & \\
\hline
\end{tabular}

DATA TRANSMITTED

16.

\begin{tabular}{l|l|l|l}
$\begin{array}{l}\text { (C) Sheet } \\
\text { No. }\end{array}$ & $\begin{array}{c}\text { (D) Rev. } \\
\text { No. }\end{array}$ & (E) Title or Description of Data Transmitted \\
\end{tabular}

\begin{tabular}{|c|c|c|c|}
\hline (F) & $(G)$ & $(H)$ & $(I)$ \\
\hline $\begin{array}{c}\text { Approval } \\
\text { Desig- } \\
\text { nator }\end{array}$ & $\begin{array}{c}\text { Reason } \\
\text { for Trans- } \\
\text { mittal }\end{array}$ & $\begin{array}{c}\text { Origi- } \\
\text { nator } \\
\text { Dispo- } \\
\text { stion }\end{array}$ & $\begin{array}{c}\text { Receiv- } \\
\text { er } \\
\text { Dispo- } \\
\text { sition }\end{array}$ \\
\hline SQ & 1 & 1 & 1 \\
\hline & & & \\
\hline & & & \\
\hline & & & \\
\hline
\end{tabular}

KEY

\begin{tabular}{|c|l|}
\hline Approval Designator (F) & \\
\hline E, S, Q, D OR N/A & 1. Approval \\
(See WHC-CM-3-5, & 2. Release \\
Sec. 12.7) & 3. Information \\
\hline
\end{tabular}

Reason for Transmittal (G)

\begin{tabular}{l|ll} 
4. Review & 1. Approved & 4. Reviewed no/comment \\
5. Post-Review & 2. Approved w/comment & $\begin{array}{l}\text { 5. Reviewed w/comment } \\
\text { 6. Dist. (Receipt Acknow. Required) }\end{array}$ \\
\hline
\end{tabular}
17.

SIGNATURE/DISTRIBUTION

(See Approval Designator for required signatures)

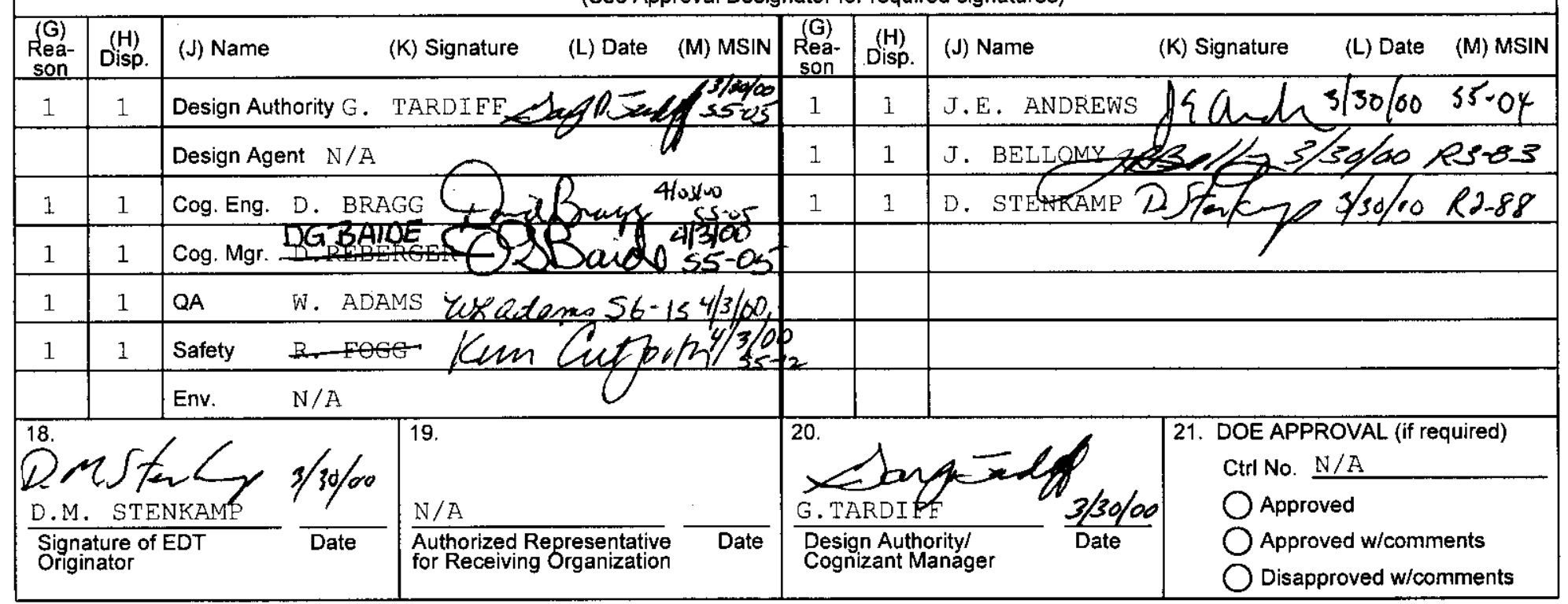




\title{
Operational Test Report For The 241-AZ-101 Suspended Solids Profiler
}

\author{
Daniel M. Stenkamp, Maintenance Concepts \\ Richland, WA 99352 \\ U.S. Department of Energy Contract DE-AC06-96RL13200

$\begin{array}{lll}\text { EDT/ECN: } & 629070 & \text { UC: } \mathrm{n} / \mathrm{a} \\ \text { Org Code: } 79 \mathrm{c00} & \text { Charge Code: } 106843 \\ \text { B\&R Code: } \mathrm{n} / \mathrm{a} & \text { Total Pages: } 42\end{array}$

Key Words: Operational test report, Project W-151, RPP-6133, Suspended So lids Profiler

Abstract: This document comprises the Operational Test Report for the 241Az-101 Suspended Solids Profiler.

TRADEMARK DISCLAIMER. Reference herein to any specific commercial product, process, or service by trade name, trademark, manufacturer, or otherwise, does not necessarily constitute or imply its endorsement, recommendation, or favoring by the United States Government or any agency thereof or its contractors or subcontractors.

Printed in the United States of America. To obtain copies of this document, contact: Document Control Services, P.O. Box 950, Mailstop H6-08, Richland WA 99352, Phone (509) 372-2420; Fax (509) 376-4989.
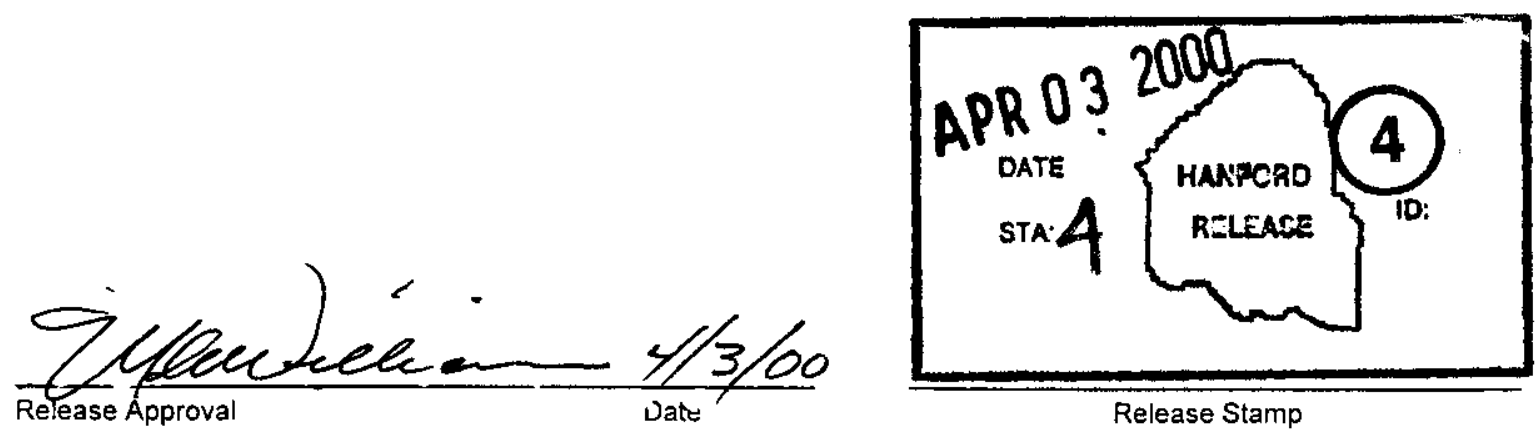

Approved For Public Release 
RPP-6133, Rev 0

\author{
RPP-6133, Rev 0 \\ Operational Test Report \\ For The 241-AZ-101 \\ Suspended Solids Profiler
}


RPP-6133, Rev 0

TABLE OF CONTENTS

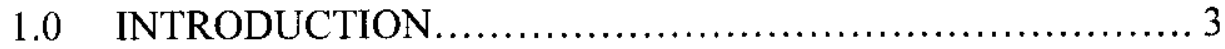

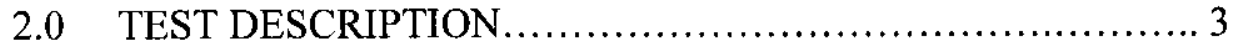

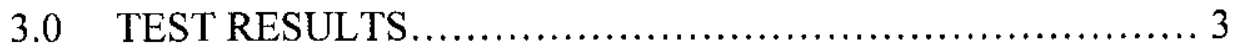

4.0 CONCLUTIONS ...................................... 4

ATTACHMENT 1

COMPLETED COPY OF OTP-260-005

A1-1 
RPP-6133, Rev 0

\subsection{INTRODUCTION}

This document presents the results of Operational Testing of the 241-AZ-101 Suspended Solids Profiler (SSP). Testing of the SSP was performed in accordance with OTP-260005, "SUSPENDED SOLIDS PROFILER OPERATIONAL TEST PROCEDURE". The objective of the testing was to verify that all equipment and components functioned as designed, following construction completion and turnover to operations.

\subsection{TEST DESCRIPTION}

Testing of the SSP was accomplished in two days. Test procedure OTP-260-005 required four revisions prior to testing to incorporate Procedure Change Authorizations (PCA's) necessary to facilitate testing. Specific equipment tested by OTP-260-005 included the following:

- Suspended Solids Profiler

- SSP personnel computer and software

- One SSP control switch

- One SSP interlock/rake switch

- One SSP emergency stop switch

\subsection{TEST RESULTS}

All testing of the 241-AZ-101 SSP system was completed satisfactorily. No equipment operational or performance deficiencies were identified which would preclude safe operations.

During the course of testing, one test exception was identified. The problem identified on the test exception has been resolved and appropriately closed. The test exception is summarized on the next page. 
RPP-6133, Rev 0

\section{Test Exception 1}

Test exception 1 identified that the SSP computer did not save the data to a floppy disk.

Step 5.4.9.3 of the test procedure detailed the keystrokes required on the SSP computer for the SSP software program to "Send to Disk". This portion of the test was to verify that the data from the SSP could be saved electronically. Initial interpretation was that the "Send to Disk" statement on the SSP menu referred to a floppy disk. The vendor software "Send to Disk" statement refers to the computer hard disk. The data can then be copied from the hard disk to a floppy disk and printed as per step 5.4 .10 of the test procedure. Therefore the system was accepted and no retest was required.

\subsection{CONCLUSIONS}

The test procedure is acceptable as written and performed. As a result of testing performed under OTP-260-005, it can be concluded that the SSP system is in a state of readiness that will support planned mixer pump test operations. 
RPP-6133, Rev 0

\section{ATTACHMENT 1 \\ COMPLETED COPY OF OTP-260-005}

A1-1 


\section{SUSPENDED SOLIDS PROFILER \\ OPERATIONAL TEST PROCEDURE}

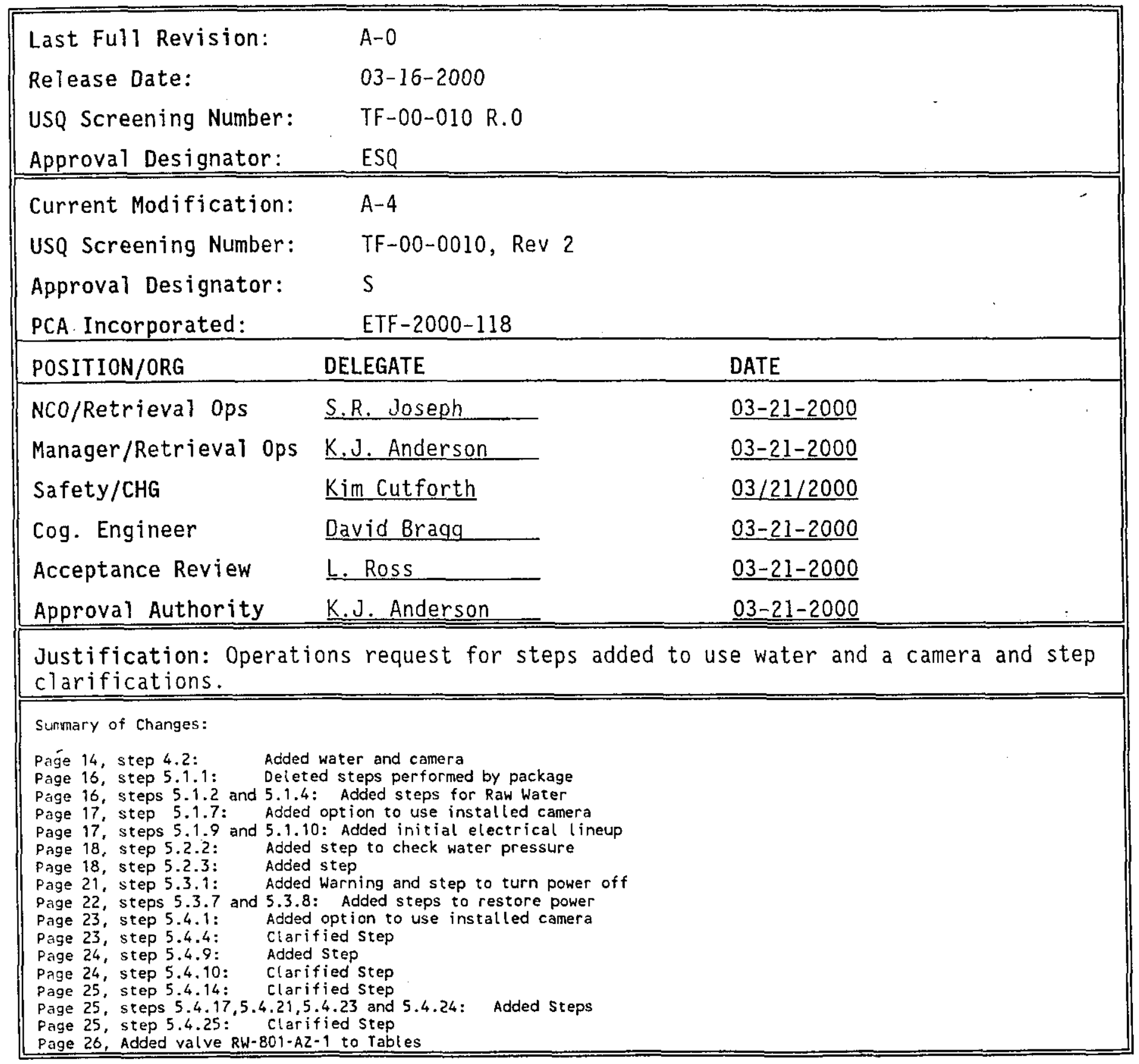

Al-2

RPP-6133, Rev 0

\begin{tabular}{|c|c|c|c|c|}
\hline CONTINUOUS & OTP $260-005$ & Rev/Mod & Reterse batro $03 / 21 / 2000$ & Pas? , of 32 \\
\hline
\end{tabular}




\section{TABLE OF CONTENTS}

TEST EXECUTION SHEET . . . . . . . . . . . . . . . . 3

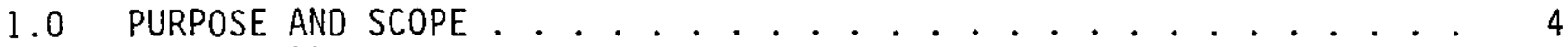

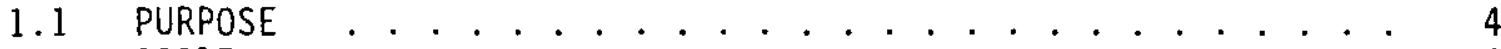

1.2 SCOPE ...................... 4

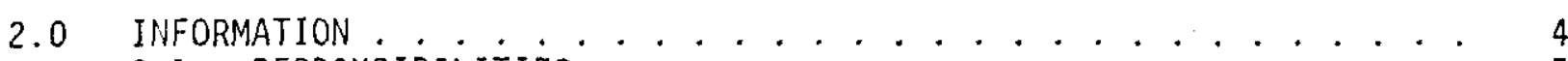

2.1 RESPONSIBILITIES . . . . . . . . . . . . . . . . . . . . . 5

2.2 REFERENCES . . . . . . . . . . . . . . . . . 7

2.3 GENERAL INFORMATION ................ 8

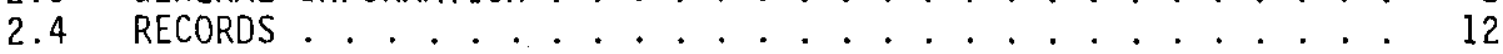

3.0 PRECAUTIONS AND LIMITATIONS . . . . . . . . . . . . . 13

3.1 PERSONNEL SAFETY . . . . . . . . ....... 13

3.2 RADIATION AND CONTAMINATION CONTROL ........... 13

3.3 LIMITS . . . . . . . . . . . . . . . . . . . . 13

4.0 PREREQUISITES . . . . . . . . . . . . . . . . . . . . . 14

4.1 SPECIAL TOOLS, EQUIPMENT, AND SUPPLIES . . . . . . . 14

4.2 PERFORMANCE DOCUMENTS . . . . . . . . . . . . . . 14

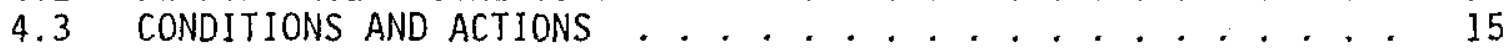

5.0 PROCEDURE . . . . . . . . . . . . . . . . . 16

5.1 TEST SET UP . . . . . . . . . . . . . . . . . . 16

5.2 TEST E-STOP AND STOP FUNCTIONS . . . . . . . . . . . . 18

5.3 OPERATION TEST SET UP . . . . . . . . . . . . . . . . 20

5.4 SUSPENDED SOLIDS PROFILER OPERATION TEST . . . . . . . 23

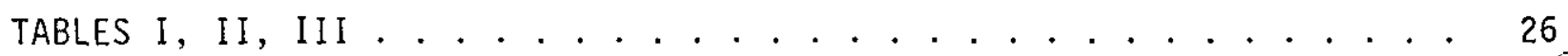

FIGURE $1 \ldots \ldots . \ldots \ldots$. . . . . . . . . . . . . . . 27

FIGURE II . . . . . . . . . . . . . . . . . 28

- OPERATIONAL TEST PROCEDURE PERFORMANCE LOG . . . . . . . . . 29

OPERATIONAL TEST PROCEDURE EXCEPTION LOG ............ 30

OPERATIONÁL TEST PROCEDURE EXCEPTION RECORD . ............ 31

PROCEDURE SIGNATURE SHEET . . . . . . . . . . . . . . . 32

\section{Al-3}

RPP.6133, Rev 0

\begin{tabular}{|c|c|c|c|c|}
\hline COI & $\begin{array}{l}\text { oociment po: } \\
\text { OTP-260-005 }\end{array}$ & 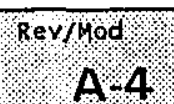 & $\begin{array}{l}\text { Retense date } \\
03 / 27 / 2000\end{array}$ & Poge: 2 \\
\hline
\end{tabular}




\section{TEST EXECUTION SHEET}

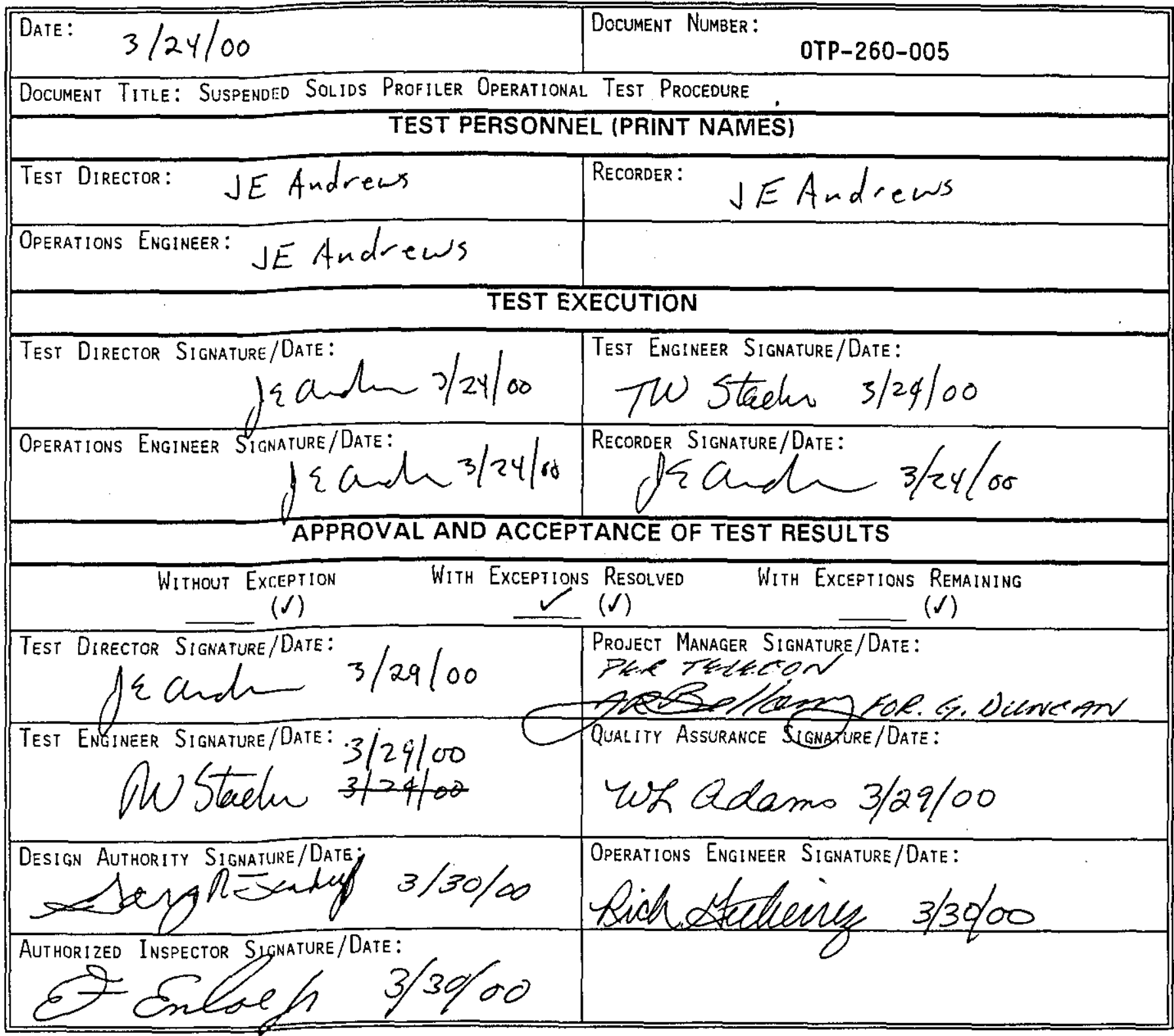




\subsection{PURPOSE AND SCOPE}

\subsection{PURPOSE}

The purpose of this test is to provide a documented means of verifying that the functional components of the Suspended Solids Profiler operate properly.

\subsection{SCOPE}

The objective of the test is to verify the operation of the Suspended Solids Profiler using a manually controlled Rake Switch and to verify data collection using a stand alone software program.

\subsection{INFORMATION}

This procedure will be done in conjunction with an approved Job Control System Work Package. AlT limits and associated controls will be specified in the work package. 


\section{1 RESPONSIBILITIES}

2.1.1 Test Engineer is responsible for the following:

- Ensuring all preparations for this Test have been completed

- Support Test Director and Test Personnel with the technical information and support necessary to complete this procedure.

2.1.2 Test Director has the option to assign a designated Recorder to fulfill the following recording criteria.

- Record, check off, initial, enter N/A, and ensure verification signatures are obtained as each step and section completes.

2.1.3 Operation Personnel are responsible for operating the equipment per the Test Engineer and Test Directors direction.

2.1.4 QC Inspector is responsible for witnessing test execution and signing the completed sections of the test.

2.1.5 The Authorized Inspector is responsible for the following:

- Witnessing test execution

- Approval and signature of acceptance upon completion of this procedure. 


\subsection{RESPONSIBILITIES (Cont).}

2.1.6 Test Director is responsible for the following:

- The safe, efficient, and productive performance of the test

- Coordination of all testing activities

- Scheduling and conducting a pre-job meeting with test participants

- Notification of the persons performing and witnessing the test prior to the start of testing

- Notification of all involved test personnel when a change is made in the testing schedule

- Acting as liaison between the participants involved with the testing

- Stopping any test or section which may cause damage to the system

- Obtaining revisions to the Test Procedure, to comply with authorized field changes or to accommodate existing field conditions

- Taking actions to resolve exceptions to the Test Procedure

- $\quad$ Signing the Operational Test Procedure Exception Record when a test exception has been resolved

- Evaluating recorded data, discrepancies, and exceptions

- Signing Test Execution Sheet when this Test Procedure has been performed

- Signing Exception Record when a retest to clear an exception has been executed and accepted

- Obtaining required signatures on the Test Procedure Working Copy prior to reproduction and distribution

- Preparing and issuing an Operational Test Report for the approved, accepted and completed Test Procedure 


\subsection{REFERENCES}

\section{Drawings}

$H-2-68423$, Sh. 1 Tank Riser Air Lift Circulator Details

$\mathrm{H}-2-78948$, Sh. 7-9 H-2-78981, Sh. 3

Elec./Inst. Equipment Interconnection Diagram

H-2-78982, Sh. 2 Tank AZ-101 Junction Box JB156-01 Wiring diagram Control Console AZ-101-156 Assembly

H-2-78983, Sh. 3,4 Console AZ-101-156 Wiring Diagram

H-2-78984, Sh. 1,2 Console AZ-101-156 Cable Assemblies

H-2-79212, Sh. 1,4,7,9 Elec/Instr/JB/Cnd Instaltation Tank AZ-101

H-2-822934, Sh. 1-11 Suspended Soljds Monitor Assembly

$\mathrm{H}-2-825974$, Sh. 1,2,3 Junction Box JB156-02 Assembly

H-2-825882, Sh. 1,2 INSTM Junction Box Assemblies

H-14-021807, Sh. 2 Raw water System RW 0\&M System P\&ID

ECN \# 710457

T0-040-540 Water Surveillance And Usage

\section{Vendor Information}

- Mt. Fury Company, PROFILER SLUDGE BLANKET LEVEL DETECTOR \& SUSPENDED SOLIDS MONITOR Installation, Operation and

Maintenance Instructions, Issaquah, Washington. VIN 0022515 , Supp. 041

other

- Procedure T0-020-265 latest revision

- USQ TF-97-0155 Rev. 1, Installation of Suspended Solids Profiler Monitor on Aging Waste Tank AZ-101

- Flammable Gas Equipment Advisory Board Interpretation/ Recommendation Report, FGEAB-97-038

- Staehr, T.W., 1996, Decant Pump Assembly and controls Qualification Testing Test Report, WHC-SD-ER3297-TRP-001, Rev. O, Westinghouse Hanford Company, Richland, Washington 


\subsection{GENERAL INFORMATION}

\section{SUSPENDED SOLIDS PROFILER}

2.3.1 The Mt. Fury Suspended Solids Profiler (SSP) is a microprocessor based suspended solids sensor with a stepping motor driven cable reel. The Suspended Solids Profiler is used commercially for the control of clarifiers and thickeners in waste treatment facilities by measuring the turbidity versus depth and also for determining the depth of the sludge blanket. The sensor uses a reflectance measurement principle to determine suspended solids concentrations. The Suspended Solids Profiler has been mounted in an enclosure assembly that was specially designed and fabricated for use on Hanfords underground storage tanks. The Suspended Solids Profiler was originally to be used to measure supernatant clarity during a decant and refill demonstration test in 1994, however the test was canceled. The Suspended Solids Profiler is currently planned to be used during mixer pump testing to provide data for determining sludge mobilization uniformity and settiing rates.

2.3.2 The Suspended Solids Profiler system consists of two major components: (1) The Suspended Solids Profiler Assembly, and the Monitoring and Control System.

2.3.3 Suspended Solids Profiler Assembly

- Suspended Solids Profiler enclosure and shielding ball valve

- Electronics box

- Suspended solids sensor and motor driven cable reel

\subsubsection{Monitoring and Control System}

- Personal computer

- External Rake Switch

- Power and signal cables

\begin{tabular}{|c|c|c|c|c|}
\hline Type & Document No. & $\mathrm{Rev} / \mathrm{Mod}$ & Release Date & page \\
\hline CONTINUOUS & OTP $260-005$ & $\mathrm{~A}-4$ & $03 / 21 / 2000$ & 8 of 32 \\
\hline
\end{tabular}




\subsection{GENERAL INFORMATION (Cont).}

PROCEDURAL INFORMATION

2.3.5 All entries recorded in this procedure shatl be made in black ink.

2.3.6 Procedural and technical requirement changes must be processed by Procedure Change Authorization in accordance with approved procedures. If a need for such a change is discovered in the course of running the test, the applicable portion of the test shall be stopped, and the test equipment shall be placed in a safe configuration, until the Procedure Change Authorization is approved. However, this does not prevent the running of another portion of the test unaffected by the change.

2.3.7 Operational Test steps detailed in individual Tests in Section 5.0 shall be performed sequentially, unless otherwise noted or as directed by the Test Director.

- As each step is completed, each step will be checked off (or enter "N/A" for), as required in the spaces provided on the Working Copy of this Operational Test Procedure

- Any step that requires verification of data must include recording data on the Working Copy.

2.3.8 Any non-conformance of the instrumentation, unexpected results or exceptions during testing shall be sequentially numbered and recorded in the Operational Test Procedure Exception $\log$ and on individual Operational Test Procedure Exception Records. Thus, case-by-case resolution, recording, approval, and distribution of each exception will be achieved. 


\subsection{GENERAL INFORMATION (Cont).}

2.3.9 Resolve test exceptions in the following manner:

- Record the action taken to resolve each exception in the "Resolution of Exception" section of the Operational Test Procedure Exception Record.

- When the action taken results in an acceptable retest, initial and date the Correction Approval section of the Exception Sheet

- When the action taken does not result in an acceptable retest, provide a detailed explanation of why the retest action was not acceptable, and what additional plans are required. The Test Engineer then signs and dates the Resolution of Exception section of the Operational Test Procedure Exception Record, and obtains any other approvals required

2.3.10 Upon completion of the Operational Test Procedure, obtain approval of the test performance. Each Test Execution Sheet will stand alone as approval for the system under test. The Operational Test will be complete when all the outstanding tests have been performed and the Operational Test Report is prepared. The test will be approved by checking the proper response, with or without exceptions, on the Test Execution Sheet under the "Approval and Acceptance of Test Results" section of the Test Execution Sheet. 


\subsection{GENERAL INFORMATION (Cont).}

2.3.11 The following steps detail the possible conditions that may exist at the completion of the Operational Test Procedure, and the steps necessary to complete acceptance in those conditions.

2.3.11.1 The completed test may be approved without test exceptions:

- Check applicable space on Test Execution Sheet to show that the Operational Test Procedure has been performed and no exceptions have been. recorded

- Appropriate individual Test Performers will sign and date the Test Execution Sheet in the spaces provided

- Distribute requisite copies as directed by the client

- Send the Master Copy of the completed Operational Test Procedure to the client.

2.3.11.2 The completed test may be approved with exceptions resolved:

- Check applicable space on Test Execution Sheet to show that this procedure has been performed with exceptions recorded and resolved

- Appropriate individual Test Performers will sign and date the Test Execution Sheet in the spaces provided

- Distribute requisite copies as directed by the client

- Send the Master Copy of the completed Operational Test Procedure to the client.

A1-12

RPP-6133, Rev 0 


\subsection{RECORDS}

2.4.1 All personnel involved in the performance of this test shall sign in Procedure Signature Sheet.

2.4.2 Test results shall be recorded. Unless specific data is required, the signature or initials as applicable, of the person accepting the item will be entered in the blank provided to indicate compliance with the stated requirements or the successful completion of the given test step. Errors shall be corrected by crossing out the incorrect data with a single line and the correct response shall be written in the direct vicinity of the original item. The person making the correction shall initial and date the correction. A complete working copy of this procedure and any exception records generated shall be maintained as a permanent record.

2.4.3 An Exception $\log$ and Exception Record sheet is attached in the event exceptions to the test are made when the test is being performed. AlI exceptions to the test are to be dispositioned and agreed to by all witnesses. Actions taken regarding disposition are noted on the exception sheet. During the performance of this test, errors in test may be encountered which require correction or adjustment to complete the test. Such corrections are to be noted in the Operational Test Procedure and 1 isted as an exception.

2.4.4 All profiles taken in this test procedure are to be maintained by Test Engineer.

A1-13

RPP.6133, Rev 0

\begin{tabular}{|c|c|c|c|c|}
\hline Type & Document No. & Rev/Mod/ & Release bate & Page \\
\hline CONTINUOUS & OTP $260-005$ & $A-4$ & $03 / 21 / 2000$ & 12 of 32 \\
\hline
\end{tabular}




\subsection{PRECAUTIONS AND LIMITATIONS}

\subsection{PERSONNEL SAFETY}

3.1.1 Individuals shall carry out their assigned work in a safe manner to protect themselves, others, and the equipment from undue hazards and to prevent damage to property and environment.

3.1.2 Test Director shall assure the safety of all activities within their areas to prevent injury, property damage, or interruption of operation.

3.1.3 Any hazard identified during the performance of the procedure shall be reported to the Test Director IMMEDIATELY.

3.1.4 A daily shift safety briefing will be held with all test participants.

3.1.5 Performance of test activities shall always include safety and health aspects as delineated in the Operations Manuals and as directed by the Test Director.

\subsection{RADIATION AND CONTAMINATION CONTROL}

3.2.1 When performed without a work package, this procedure is limited to radiological areas and work activities permitted by a general radiation work permit.

3.2.2 When work is performed in or when work will result in a high contamination, high radiation, or an airborne radioactive area, then an approved Job Control System work package must be developed which is reviewed by Radiological Control per the ALARA procedure HNF-IP-0842, Volume VII, Section 17.1.

\subsection{LIMITS}

This procedure will be done in conjunction with an approved Job Control System Work Package. All limits and associated controls will be specified in the work package.

\begin{tabular}{|c|c|c|c|c|c|}
\hline Type & Rev/Mod & Release date & Page & ontinuous \\
\hline
\end{tabular}




\section{0 - PREREQUISITES}

\subsection{SPECIAL TOOLS, EQUIPMENT, AND SUPPLIES}

Items Provided:

- Suspended Solids Profiler assembly

- Operator $P C$ and monitor

- DATA_PRO Software program

Procured Items

- Electrical 2 position Rake Switch (Ref. ECN-629838 pg 10, dwg. $\mathrm{H}-2-78982$, sh 2, Items $85 \& 86$ )

- Signal cable assembiy, 50 feet (Ref. ECN-629838 pg 14, dwg. H-2-78984, sh 2, Item 12)

- Power cable assembly, 50 feet (Ref. ECN-629838 pg 14, dwg. H-2-78984, sh 2, Item 13)

- Computer cable assembly, 50 feet (Ref. ECN-629838 pg 13, dwg. H-2-78984, sh 1, Item 11)

- Electrical insulating putty (Ref. ECN-629838 pg 21, dwg. H-2-822934, sh 1, See note 12)

\subsection{PERFORMANCE DOCUMENTS}

The following procedures may be needed to perform this procedure:

- TO-020-265 "PERFORM MCCS SURVEY OF SINGLE SHELL OR DOUBLE SHELL WASTE STORAGE TANKS EAST AREA".

- T0-040-540 "NATER SURVELLLANCE AND USAGE".

- TO-260-210 "OPERATE 241-AZ-101. WASTE TANK COLOR VIDEO SYSTEM" 
WORKING COP

Print. on. Mar 23, 00 7:00 am

4.3 CONDITIONS AND ACTIONS

The following conditions must be met before this Operational Test Procedure (OTP) may commence.

NOTE- All signators on this procedure shall document their signature on Procedure Signature Sheet.

4.3.1 All field testing and inspection of the system or portions of the system to be tested has been completed.

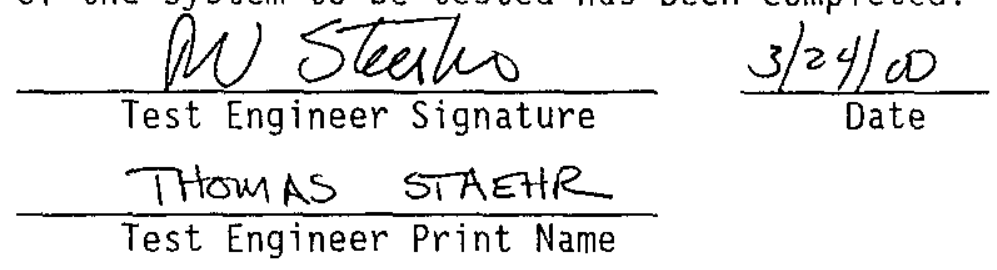

4.3.2 A pre-job briefing has been held, and all participants have been thoroughly briefed on job safety, hazards, and their responsibilities before performing this Operational Test Procedure.
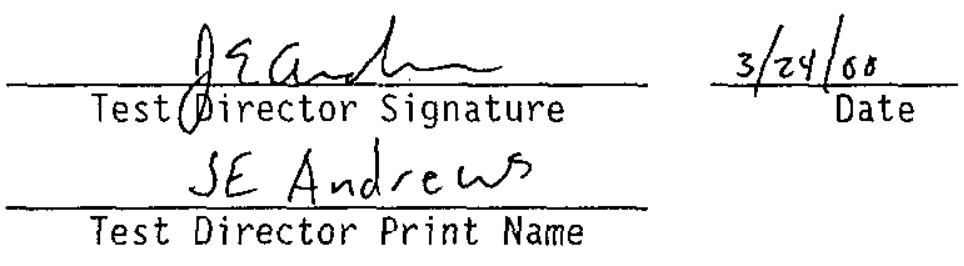

4.3.3 Test Director VERIFY Section 4.0 has been COMPLETED by SIGNING below.

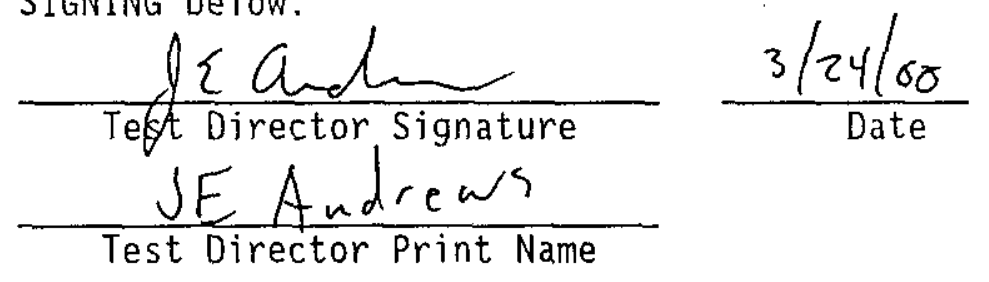

$$
\begin{aligned}
& 4.3 \text { Acceptable } \\
& \text { PAW } 3.24 .00
\end{aligned}
$$

A1-16

RPP-6133, Rev 0

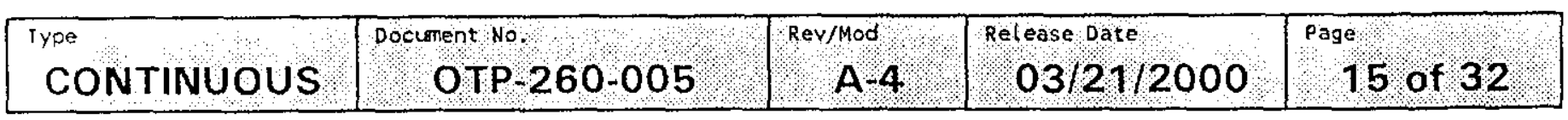




\subsection{PROCEDURE}

\section{CAUTION}

Care should be taken to not damage the flush spray ring. Do not step on, lean equipment or tools on, or in any way damage the spray ring.

\subsection{TEST SET UP}

NOTE - Installation of Suspended Solids Profiler is accomplished in an approved Job Control System work Package.

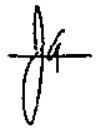

5.1.1 ENSURE the following items have been accomplished.

- Installation of Suspended Solids Profiter assembly on tank $101-A Z$ riser $24-A$.

- Power cables instalted to power-source.

- - Signal-cable wires to Rake-Switch-and to computer cable have been-installed.-

- Computer cable to Personal computer has been installed.

- Power and instrument-eables to the-suspended-Solids Profiler have been-installed-

NOTE-W. Water-supply must be- minimum of 4 -gpmat 40 100 psi.

- Water supply to the Suspended Solids Profiler spray wash ring assembly has been installed including all necessary hoses from $801 \mathrm{AZ}$ b7dg, to the SSP Unit.

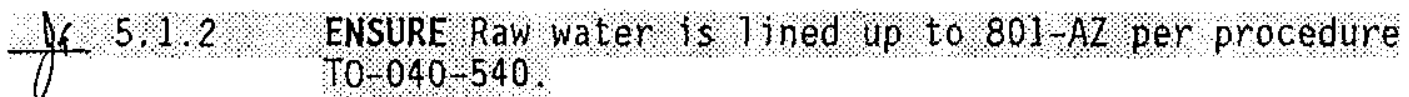

Ia 5.1.3 RECORD initial flow meter reading from AZ-101-SSP-FM-1, located at $801 \mathrm{AZ} \mathrm{Bldg}$.

0000000.2 gal

14. 5.1.4 RECORD the int to 1 water reading on the RAW WATER USAGE DATA SHEET(s) from procedure $10-040.540$. 


\subsection{TEST SET UP (Cont).}

ENSURE the DATA PRO software program is loaded in the Personal computer.

A 5.1 .6

TAKE liquid level reading from Enraf located on riser $22 \mathrm{~A}$ AND

RECORD liquid level reading below.

$\frac{309 \cdot 12^{\prime \prime}}{\text { Liquid Level Reading }}$

Ag 5.1 .7

ENSURE temporary camera system is installed in Tocation per Test Directors direction using the latest rev. of procedure T0-020-265 "PERFORM MCCS SURVEY OF SINGLE SHELL OR DOUBLE SHELL WASTE STORAGE TANKS EAST AREA"

OR

ENSURE the 241 AZ 10 l Waste Tank Color Video System 1 s operating per 10-260-210.

$f_{4} 5.1 .8$
$\frac{f}{49.9 .9} 5.10$

ENSURE Valve AZ101-SSP-5 is OPEN

ENSURE the "AUTO RAISE STOP LOWER" swT LCh is In the "STOP" postition.

ENSURE BREAKER \%5, SUSPENDED SOL IOS CABINET, 10cated in PANELBOARO EDS - DP 706 on 92101 M Mer P imp Pad in the ON pos 117 ion.

$$
\begin{gathered}
\text { Section } 5.1 \text { arreptable } \\
\text { OAW } 3.24-00
\end{gathered}
$$

A1- 18

RPP-6133, Rev 0 


\subsection{TEST E-STOP AND STOP FUNCTIONS}

NOTES - The camera may be used to watch the probe lower, stop, and raise during this section.

- The probe should begin to lower after performing the following step.

$-f_{a} 5.2 .1$
$f^{2} 5.2 .2$

ENSURE Valve Line-Up is complete per Table I.

ENSURE $40-100$ pSi is ind icated on PRE SSURE INDICATOR, at downstream side of PRESSURE REGULATOR AZ - 101 -SSP-PR-1, located inside of BUILOING 241-AZ-801A.

y $5,2,3$

ENSURE the "E-STOP" button (AZ101-WST PB-101) 10cated on the stand next to SSP IS IPULLE OUT'?

fa 5.2 .4

POSITION the "AUTO RAISE STOP LOWER" switch to the "LOWER" position.

fe 5.2 .5

ALLOW the probe to lower into tank dome space AND

PUSH in the. "E-STOP" button (AZ101-WST-PB-101) located on the stand next to SSP.

$\frac{14}{4} 5.2 .6$
$\lg 5.2 .7$

ENSURE the probe has stopped.

POSITION the "AUTO RAISE STOP LOWER" switch to the "RAISE" position.

$f 5.2 .8$

PULL out the "E-STOP" button (AZ101-WST-PB-101) located on the stand next to SSP.

fir 5.2 .9

te 5.2 .10

ENSURE the probe has begun to "RAISE" AND

The Flush system flow meter is indicating flow.

5.2 .11
-54.2 .12

WHEN the probe reaches a point just prior to its entry

into the housing box, PUSH in "E-STOP" button.

ENSURE the probe has stopped.

POSITION the "AUTO RAISE STOP LOWER" switch to the "STOP" position.

fa 5.2 .13

PULL out "E-STOP" button.

In 5.2 .14

REPEAT steps 5.2.4 - 5.2.13 one time AND CONTINUE in this procedure.

\begin{tabular}{|c|c|c|c|c|}
\hline Type: & Document No. & $\mathrm{Rev} / \mathrm{Mod}$ & Release Date & Page \\
\hline CONTINUOUS & OTP-260-005 & A. 4 . & $03 / 21 / 2000$ & 18 of 32 \\
\hline
\end{tabular}




\subsection{TEST E-STOP AND STOP FUNCTIONS (Cont).}

NOTE - The probe should begin to lower after performing the following step.

fi. 5.2 .15

POSITION the "AUTO RAISE STOP LOWER" switch to the "LOWER" position.

$f(t .2 .16$

ALLOW the probe to lower into tank dome space AND

POSITION the "AUTO RAISE STOP LOWER" switch to the "STOP" position.

fa 5.2.17 ENSURE the probe has stopped.

$-5.2 .18$

POSITION the "AUTO RAISE STOP LOWER" switch to the "RAISE" position.

$\frac{1}{6} 5.2 .19$

ENSURE the probe has begun to "RAISE" AND

The flush system flow meter is indicating flow.

fy 5.2 .20

WHEN the probe reaches a point just prior to its entry into the housing box, POSITION the "AUTO RAISE STOP LOWER" switch to the "STOP" position.

$\left\{\begin{array}{l}5.2 .21 \\ \text { f } 5.2 .22\end{array}\right.$

ENSURE the probe has stopped.

REPEAT steps 5.2.15 - 5.2.21 one time AND CONTINUE in this procedure.

fc 5.2 .23

POSITION the "AUTO RAISE STOP LOWER" switch to the "RAISE" position.

ft 5.2 .24

ENSURE When Probe is returned to the fully retracted position, it automatically stops.

La 5.2.25 With the probe in the fully retracted position, SWITCH the Motor Control Switch to the "STOP" position.

$$
\begin{gathered}
\text { Section } 5.2 \text { acceptable } \\
\text { ond } 3-24.00
\end{gathered}
$$

\begin{tabular}{|c|c|c|c|c|}
\hline Type & Docisnent $\mathrm{No}$. & Rev/Mod & Release oate & Page \\
\hline CONTINUOUS & OTP. 260.005 & A-4. & $03 / 21 / 2000$ & 19 of 32 \\
\hline
\end{tabular}




\subsection{OPERATION TEST SET UP}

NOTE - Calculation information:

Top of flange on riser $24 \mathrm{~A}$ elevation $=672.66$

(Ref Dwg.H-2-687372)

Bottom of tank elevation $=616.54$ (Ref. Dwg. H-2-67317)

Profiler plate and spool piece length $=3.83^{\prime}$

(Ref Dwg.H-2-822934)

Probe length $=.7^{\prime}($ Ref Dwg.822934)

- For Bottom calculation subtract $3^{\prime}$ to stay approximately 36 " off bottom of tank.

SEE FIGURE II

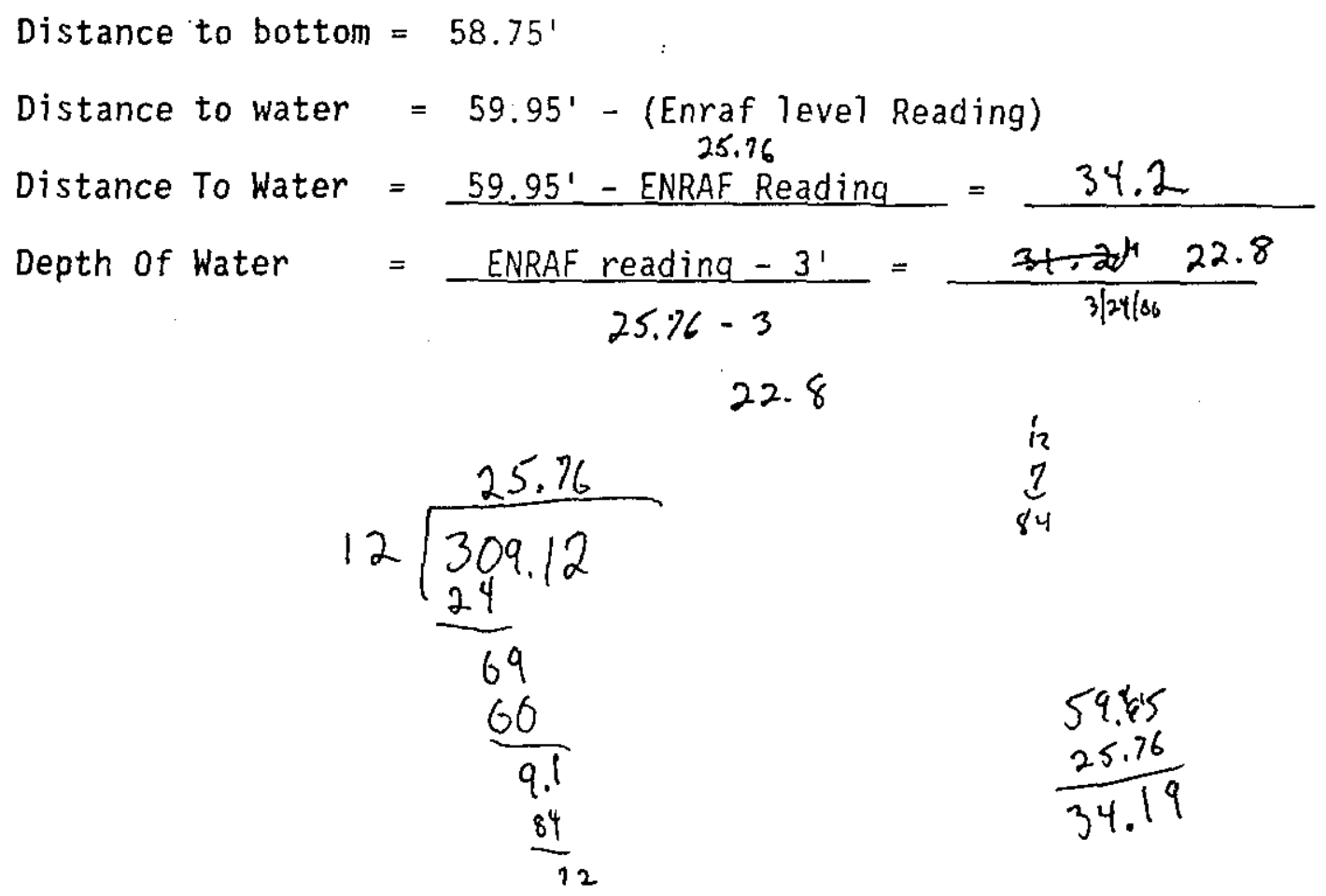




\subsection{OPERATION TEST SET UP (Cont).}

NOTE - When setting the dials for distance and depth parameters, the places are tens, ones and tenths. Therefore a setting of 99.9 feet would be dialed in as 999 on profiler dials.

\section{WARNING}

Suspended Solids Profiler main power is supplied from Panel board EDS-DP-706 Ckt. \#5 Located at 241-AZ-101. This controls the $110 \mathrm{~V}$ Power to the Suspended Solids Profiler. There is $\mathrm{stjl}$ the potential for low voltage signal circuits to be energized in the cabinet.

19.31

PLACE BREAKER $\% 5$, SUSPENDEO SOLIOS CABINET, located in PANEL BOARD EOS-DP-706 on AZ101 Mi Xer Pump Pad in the OFF postton

fa 5.3.2 On Suspended Solids Profiler, SET applicable dials to the above calculated level settings. (Ref Figure 2)

fa 5.3 .3

ENSURE dip switches $S 2$ are configured in the following positions:

\begin{tabular}{|c|c|c|}
\hline Switch & Position & Description \\
\hline 1 & Closed & $\begin{array}{l}\text { Profiler is communicating with a supervisory } \\
\text { computer and has the Profilers address set on } \\
\text { the rotary switch. }\end{array}$ \\
\hline 2 & Open & Relay contact configured for SSP Failure Alarm \\
\hline 3 & Closed & Relay contact configured for SSP Failure Alarm \\
\hline 4 & Closed & Relay contact configured for SSP Failure Alarm \\
\hline 5 & Open & 4-20mA output is internally controlled \\
\hline 6 & Open & $\begin{array}{l}\text { 4-20mA output is proportional to sludge blanket } \\
\text { depth as a percentage of the range set on } \\
\text { WATER DEPTH. The output is } 100 \%(20 \mathrm{Ma}) \text { if the } \\
\text { sludge blanket is at the deepest point } \\
\text { measured, equal to DISTANCE TO WATER added to } \\
\text { WATER DEPTH. }\end{array}$ \\
\hline 7 & Open & $\begin{array}{l}\text { "Rake Switch" close/open sequence is necessary } \\
\text { to start profiles. }\end{array}$ \\
\hline 8 & Closed & $\begin{array}{l}\text { 4-20mA output is proportional to sludge blanket } \\
\text { depth, with no sludge blanket generating a } 4 \mathrm{~mA} \\
\text { output and a sludge blanket depth equal to } \\
\text { WATER DEPTH generating a } 20 \mathrm{~mA} \text { output. }\end{array}$ \\
\hline
\end{tabular}

$\mathrm{A} 1 \cdot 22$

RPP-6133, Rev 0

\begin{tabular}{|c|c|c|c|c|}
\hline CONTINUOUS & OTP $260-005$ & Rev/Mad & $03 / 21 / 2000$ & 21 of 32 \\
\hline
\end{tabular}


WORKING COP:

Printed on: Mar 23,007:00 am

5.3 OPERATION TEST SET UP (Cont). ff 5.3.4 SET the TIME rotary dial to $09-8.5$ mint. This is the
minimum time required for the profile to complete its measurement cycle.

ff 5.3.5 SET the SETPOINT rotary dial to 99.0 . This setting will allow the profile to read suspended solids concentration of up to a maximum of approximately $6 \%$. A4 5.3.6 SET the ADDRESS rotary dial to $50 \div 0$. This is the default
setting that is used when the profited is used in the failure alarm configuration.

O6 5.3.7 ENSURE the "AUTO RATSE STOP LOWER" switch is in the "STOP"

fa. 5.3,8 ENSURE BREAKER \#5, SUSPENDED SOLIDS CABINET, located in PANELBOARD EDS -DP- 706 on Al 101 Mixer Pump Pad in the ON position.

Section 5.3 arepertable CAW $3.24-00$

A1-23

RPP-6133, Rev 0

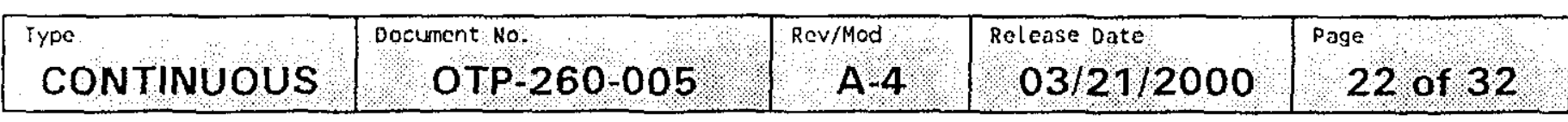




\subsection{SUSPENDED SOLIDS PROFILER OPERATION TEST}

\section{WARNING}

Suspended Solids Profiler main power is supplied from Panelboard EDS-DP-706 Ckt. \# 5 Located at 241-AZ-101. This controls the $110 \mathrm{~V}$ Power to the Suspended Solids Profiler. There is still the potential for low voltage signal circuits to be energized in the cabinet.

ft 5.4 .1

ENSURE temporary camera system is installed per procedure TO-020-265 "PERFORM MCCS SURVEY OF SINGLE SHELL OR DOUBLE SHELL WASTE STORAGE TANKS EAST AREA"

OR

ENSURE the 241 - AZ - 101 waste Tank color Video system is operating per $10-260-210$.

$f_{a} 5.4 .2$
$f^{4} 5.4 .3$
$f^{4} 5.4 .4$

ENSURE Valve LINE UP is complete per Table I.

ENSURE the software program is running on the Operators Computer.

With the probe in the fully retracted position, SWITCH the Motor Control Switch to the "AUT0" position.

NOTE - The probe spray wash should automatically activate as the probe is being raised.

- The probe should raise to the fully retracted position.

- If profiler is left in auto position then operation of Rake Switch is not necessary. If control switches have been switched to anything other than auto since the last run of the profiler then the Rake Switch must be operated twice to start the sequence.

$f^{\prime a} 5.4 .5$

INITIATE the operation of the profiler by CLOSING AND

OPENING (Activating) the Rake Switch located on Mixer Pump Control Console, in AZ-156 building, twice. 


\subsection{SUSPENDED SOLIDS PROFILER OPERATION TEST (Cont).}

NOTE - Test Engineer may choose to change the parameters of the software at any time during this procedure to determine the amount, duration, and frequency of profile data collection.

IF tank conditions permit, USE camera system to visualiy ensure probe is submerged in waste. (Ref. Figure 1)

IF probe is NOT submerged OR submerged too deep then MAKE appropriate adjustments to depth settings per Test Engineer direction.

NOTE - The probe should continue to automatically lower and stop to make measurements until a total of 20 measurements are taken.

yes 5.4 .8

ENSURE that profile readings are displayed at the Suspended Solids Profiler Personal computer monitor using the alphanumeric screen and graphics screen in AZ-156 building.

SAVE SUSPENDED SOL IOS PROFLLR system data, as follows.

\section{4 .9 .1 PRESS $\angle E S C>$ Key AND}

CHECK that the "Type a Number" nenu is displayed.

5.4 .9 .2 PRESS $<3>$ key (V lew 0ata $P 1 /$ ) AND

CHECK that the "RISER 24 A SSP' screen is displayed.

5.4 .9 .3 PRESS the 22 . key (Send to Disk) on the RISER 24 A SSP" menu.

th 5.4 .10

NOTE -

$\mathrm{H}^{5.4 .11}$
REQUEST Test Engineer retrleve-RECORO electronically and hard copy of all profile data taken.

After the final measurement has been taken, the probe should automatically begin to raise. The probe should raise to the fully retracted position and stop when it touches the contact plate. The probe spray wash should automatically activate as the probe is being raised.

ENSURE the flushing system activates as probe starts to raise. 


\subsection{SUSPENDED SOLIDS PROFILER OPERATION TEST (Cont).}

fh 5.4 .12

$f^{5.4 .13}$

$f^{14} 5.4 .14$

$\frac{f}{f} 5.4 .15$

f) 5.4 .16

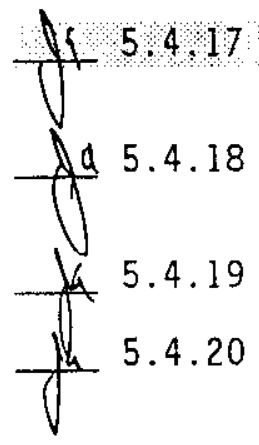

$\frac{4}{4} \cdot 4.21$
$f(5.4 .22$
$y .4 .23$

$f 4.5 \cdot 4 \cdot 24$

fy 5.4 .25
WHEN probe has raised above the waste level, AND entered into dome space, POSITION the "AUTO RAISE STOP LOWER" switch to the "STOP" position.

PERFORM steps 5.2.15 - 5.2.21 in any order, as many times as necessary per Test Director or HPT, to FLUSH cable and probe.

POSITION the "AUTO RAISE STOP LOWER" switch to the MRAISE" "AUTO" position.

ENSURE the probe stops raising when it touches the contact plate.

ENSURE the flush system deactivates after probe stops on contact plate.

POSITION the "AUTO RAISE STOP LOWER" switch to the "STOP" posittion.

BLEED OFF flush system pressure, in accordance with valve Line-Up Table II.

ENSURE Valve Line-Up is complete per Table III.

RECORD flow meter reading from AZ-101-SSP-FM-1, located at $801 \mathrm{AZ}$ Bldg.

$$
90.3
$$
gai.

RECORD the f inal water reading on the RAW WATER USAGE OATA SHEET ( $S$ ) from procedure $10-040-540$.

ENSURE hoses are disconnected.

PLACE BREAKER 15 . SUSPENOEO SOL IOS CABINET, $10 \mathrm{Cated} 1 \mathrm{I}$ PANELBOARD EDS OP 706 on 97101 1/ 1 er Pump Pad in the OFF posttion.

IF directed, SECURE raw water to 801 -A7 per procedure $70-040-540$.

VERIFY Section $5.4-5-2$ is completed satisfactorily.

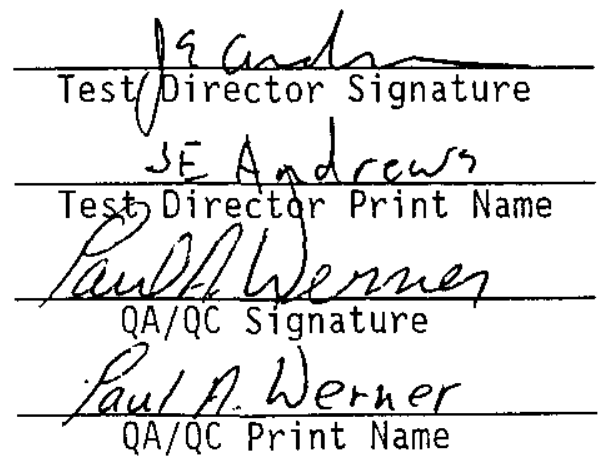

A1-26
RPP-6133, Rev 0 
TABLES I, II, III

TABLE I VALVE LINE-UP FOR FLUSH

\begin{tabular}{|c|c|c|}
\hline VALVE ID. NUMBER & $\begin{array}{l}\text { VALVE POSITION } \\
\text { FOR STEP } \\
5.2 .1 \text {. }\end{array}$ & INITIAL / DATE \\
\hline $\begin{array}{l}\text { 2" Gate Vaive Inside } 801 \cdot \mathrm{AZ} \text { Bldg. } \\
\text { AZ801A-RW-V-103 }\end{array}$ & OPEN & rew ' 3/28loa \\
\hline AZ101-SSP-1 At 801-AZ B1dg & OPEN & Fxu $13 / 25 / 00$ \\
\hline AZ101-SSP-2 At 801-AZ BIdg & OPEN & $7 x 21312400$ \\
\hline $\mathrm{RW}-801-\mathrm{AZ}-1$ at $801-\mathrm{AZ}$ Bldg & CLOSED & TKu 1364100 \\
\hline $\begin{array}{l}\text { 3/4" Gate Valve at hose connector } \\
801-A Z \text { BTdg. AZ801A-RW-V-104 }\end{array}$ & CLOSED & TXN ' 3/28100 \\
\hline
\end{tabular}

TABLE II VALVE LINE-UP FOR FLUSH SYSTEM VENTING

\begin{tabular}{|c|c|c|}
\hline VALVE ID. NUMBER & $\begin{array}{l}\text { VALVE POSITION } \\
\text { FOR STEP } 5.4 .18 .\end{array}$ & INITIAL / DATE \\
\hline AZ101-SSP-2 At 801-AZ Bldg & OPEN & $11328 / 02$ \\
\hline AZ101-SSP.1 At 801-AZ B Bdg & OPEN & $54 / 3 / 28 / 00$ \\
\hline $\begin{array}{l}\text { 2" Gate Valve Inside } 801 \cdot \mathrm{AZ} \text { B7dg. } \\
\text { AZ801A-RW-V-103 }\end{array}$ & CLOSED & $3013 / 28 / 00$ \\
\hline $\mathrm{RW}-801-\mathrm{AZ}-1$ at $801-\mathrm{AZ} \mathrm{Bldg}$ & CLOSED & $s R=13 / 28 / 00$ \\
\hline $\begin{array}{l}\text { 3/4" Gate Valve at hose connect } \\
801-\mathrm{AZ} \text { B } 1 \mathrm{dg} \text {. AZ801A-RW-V-104 }\end{array}$ & OPEN & $S R 2+3 / 2800$ \\
\hline
\end{tabular}

TABLE III VALVE LINE-UP FOR FLUSH SYSTEM SHUTDOWN

\begin{tabular}{|c|c|c|}
\hline VALVE ID. NUMBER & $\begin{array}{l}\text { VALVE POSITION } \\
\text { FOR STEP } 5.4 .19 .\end{array}$ & INITIAL / DATE \\
\hline AZ-101-SSP-2 At 801-AZ BIdg & CLOSED & sit $13 / 25 / 10$ \\
\hline$A Z-101-S S P-1$ At $801-A Z$ BIdg & CLOSED & $53413 / 28 / 0$ \\
\hline $\begin{array}{l}\text { 2" Gate Vaive Inside } 801-A Z \text { Bidg. } \\
\text { AZ801A-RW-V-103 }\end{array}$ & CLOSED & Sty $13 / 28 / \infty$ \\
\hline RW- $801-A Z-1$ at $801-A Z$ B $d \mathrm{dg}$ & CLOSED & $541328 \%$ \\
\hline $\begin{array}{l}\text { 3/4" Gate Vaive at hose connector } \\
801-A Z \text { B } d \text { dg. AZ801A-RW-V.104 }\end{array}$ & CLOSED & ser ${ }^{\prime} 3 / 28 / 0$ \\
\hline
\end{tabular}

Al-27

RPP-6133, Rev 0

\begin{tabular}{|l|l|l|l|l|l|}
\hline Type \\
CONTINUOUS
\end{tabular}


TABLES I, II, III

TABLE I VALVE LINE-UP FOR FLUSH

\begin{tabular}{|c|c|c|}
\hline VALVE ID. NUMBER & $\begin{array}{l}\text { VALVE POSITION } \\
\text { FOR STEP } \\
5.2 .1 .\end{array}$ & INITIAL / DATE \\
\hline $\begin{array}{l}\text { 2" Gate Valve Inside } 801-A Z \text { Bldg. } \\
\text { AZ801A-RW-V-103 }\end{array}$ & OPEN & $13 / 24 / 66$ \\
\hline AZ10I-SSP-I At 801-AZ BIdg & OPEN & $13 / 24 / 00$ \\
\hline AZ101-SSP-2 At 801-AZ B1 dg & OPEN & $13 / 24 / 00$ \\
\hline $\mathrm{RW}-801-\mathrm{AZ}-1$ at $801-\mathrm{AZ} \mathrm{B} 1 \mathrm{dg}$ & CLOSED & $13 / 24 / 08$ \\
\hline $\begin{array}{l}3 / 4^{\prime \prime} \text { Gate Valve at hose connector } \\
801-A Z \text { B } 1 \text { dg. AZ801A-RW-V-104 }\end{array}$ & CLOSED & $13 / 24 / 00$ \\
\hline
\end{tabular}

TABLE II VALVE LINE-UP FOR FLUSH SYSTEM VENTING

\begin{tabular}{|c|c|c|}
\hline VALVE ID. NUMBER & $\begin{array}{l}\text { VALVE POSITION } \\
\text { FOR STEP } 5.4 .18 \\
\end{array}$ & INITIAL / DATE \\
\hline AZ101-SSP-2 At $801-A Z$ Bldg & OPEN & $13-24 \cdot c x$ \\
\hline AZ101-SSP-I At 801-AZ Bl dg & OPEN & $13.24-00$ \\
\hline $\begin{array}{l}\text { 2". Gate Valve Inside } 801-A Z \text { Bldg. } \\
\text { AZ801A-RW-V-103 }\end{array}$ & CLOSED & $08 \quad 13-34-00$ \\
\hline $\mathrm{RH}-801-\mathrm{AZ}-1$ at $801-\mathrm{AZ} \mathrm{B} 1 \mathrm{dg}$ & CLOSED & $13.24-0$ \\
\hline $\begin{array}{l}3 / 4^{\prime \prime} \text { Gate Valve at hose connector } \\
801-A Z \text { Bldg. AZ801A-RW-V-104 }\end{array}$ & OPEN & $13-2 i 1-\infty$ \\
\hline
\end{tabular}

TABLE III VALVE LINE-UP FOR FLUSH SYSTEM SHUTDOWN

\begin{tabular}{|c|c|c|}
\hline VALVE ID. NUMBER & $\begin{array}{l}\text { VALVE POSITION } \\
\text { FOR STEP } 5.4 .19 .\end{array}$ & INITIAL / DATE \\
\hline$A Z-101-S S P-2$ At $801-A Z$ Bldg & CLOSED & $1334 \times 0$ \\
\hline$A Z-101-S S P-1$ At $801-A Z$ B] dg & CLOSED & $13-4=00$ \\
\hline $\begin{array}{l}\text { 2" Gate Valve Inside } 801-A Z \text { Bldg. } \\
\text { AZ801A-RW-V-103 }\end{array}$ & CLOSED & $\mid 3-24-\infty$ \\
\hline $\mathrm{RW}-801-\mathrm{AZ}-1$ at $801-\mathrm{AZ} \mathrm{Bldg}$ & CLOSED & $1324 \cdot \mathrm{co}$ \\
\hline $\begin{array}{l}3 / 4 " \text { Gate Valve at hose connector } \\
801-A Z \text { Bldg. AZ801A-RW-V-104 }\end{array}$ & CLOSED & $48 \quad 1324$ \\
\hline
\end{tabular}

A1-28

RPP-6133, Rev 0

\begin{tabular}{|c|c|c|c|c|}
\hline CONTINUOUS & Document ${ }^{\text {ro. }}$ OTP $260-005$ & $\begin{array}{r}\text { Rev/Mod } \\
\text { A }-4\end{array}$ & $03 / 21 / 2000$ & 26 of 32 \\
\hline
\end{tabular}




\section{FIGURE 1}

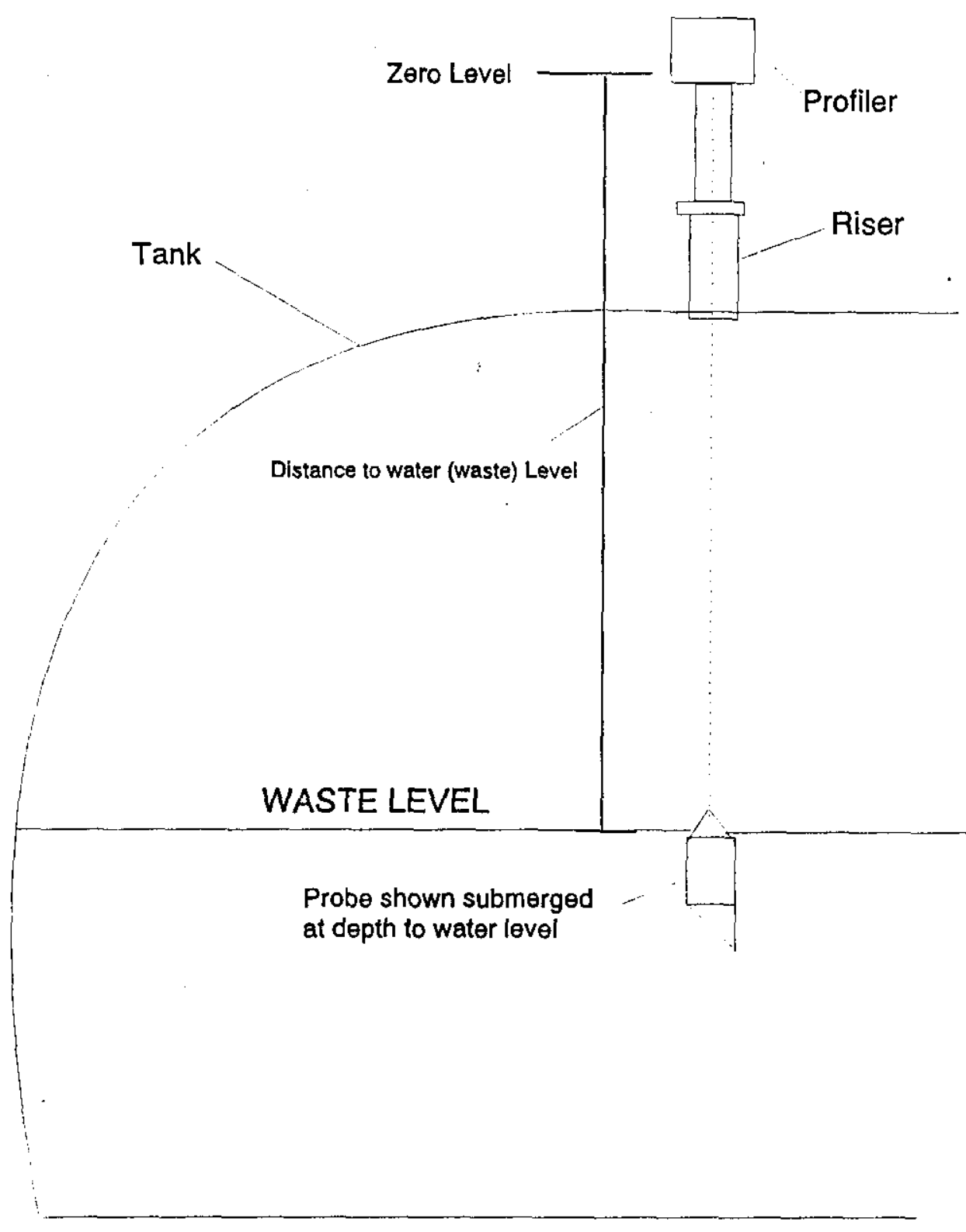

$A 1 \cdot 29$

RPP.6133, Rev 0 


\section{FIGURE II}

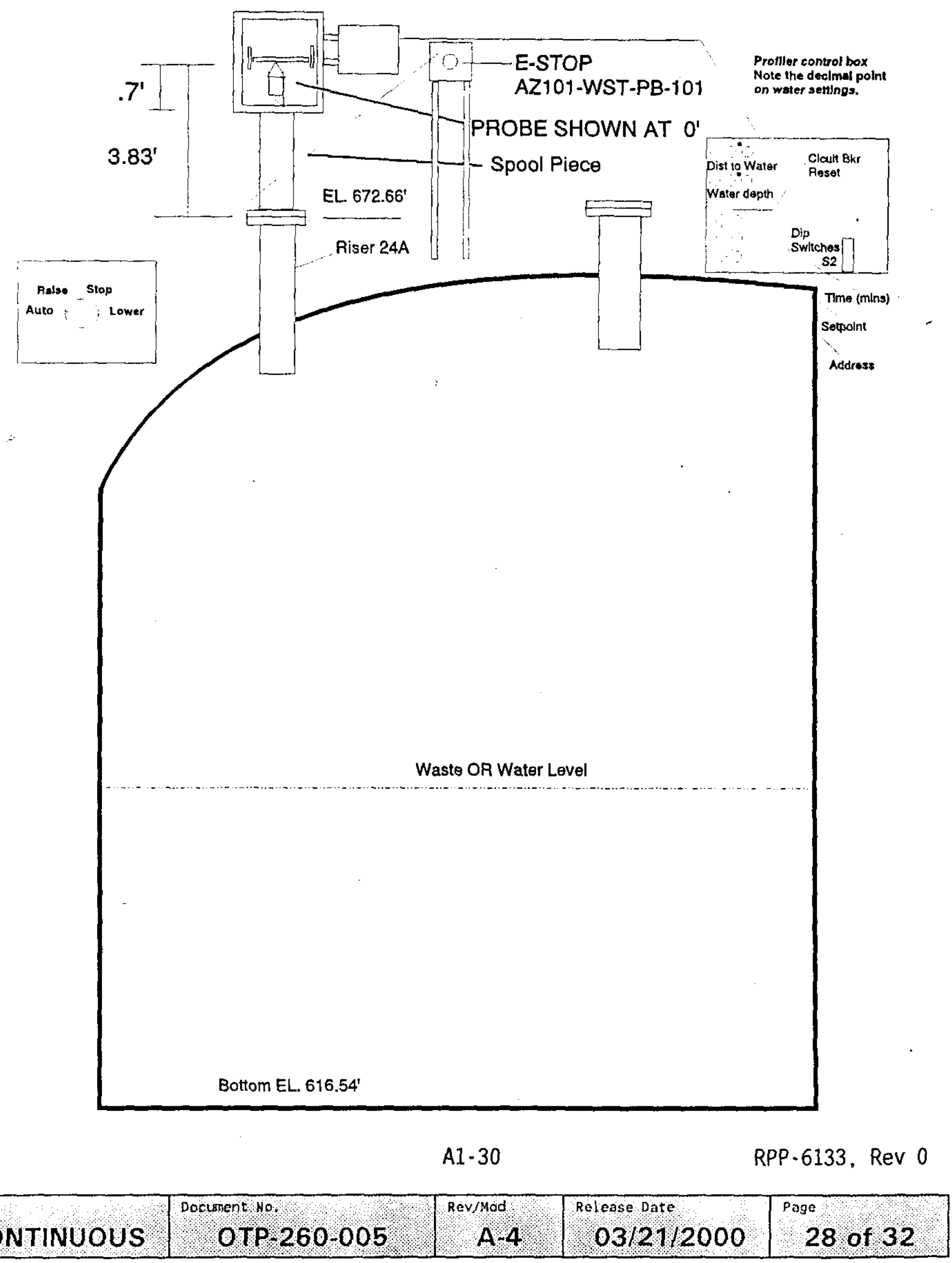


WORKING COP

Printed on, Mar $23,007,00$ an

OPERATIONAL TEST PROCEDURE PERFORMANCE LOG

This page may be reproduced as necessary. Page _ _ of

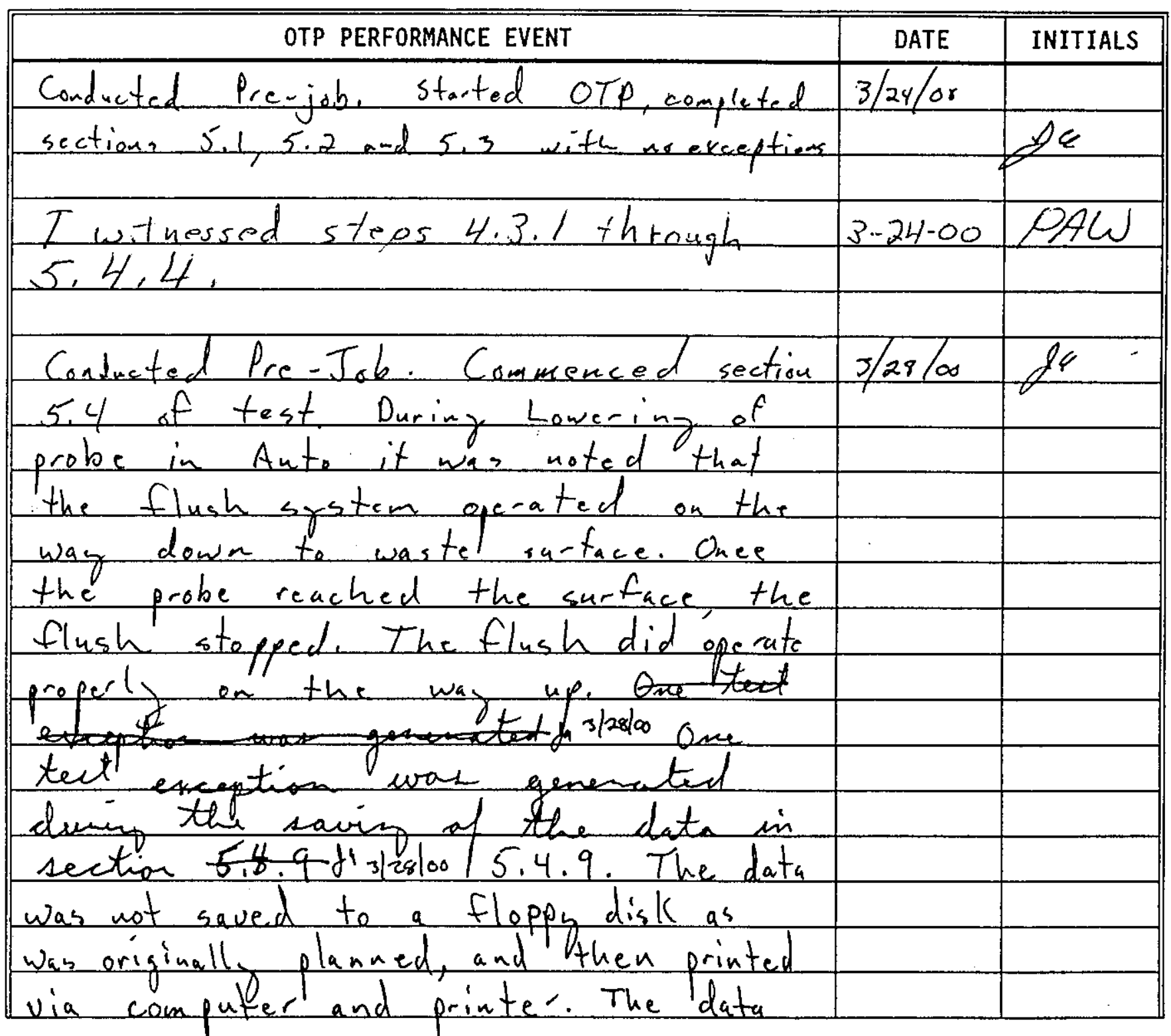

A1-31

RPP-6133, Rev 0

\begin{tabular}{|c|c|c|c|c|c|}
\hline Type & Rev/Mod & Release Date \\
CONtINUOUS & OT $260-005$ & Al & $03 / 21 / 2000$ & Page & 29 of 32 \\
\hline
\end{tabular}




\section{OPERATIONAL. TEST PROCEDURE PERFORMANCE LOG}

This page may be reproduced as necessary. Page 2

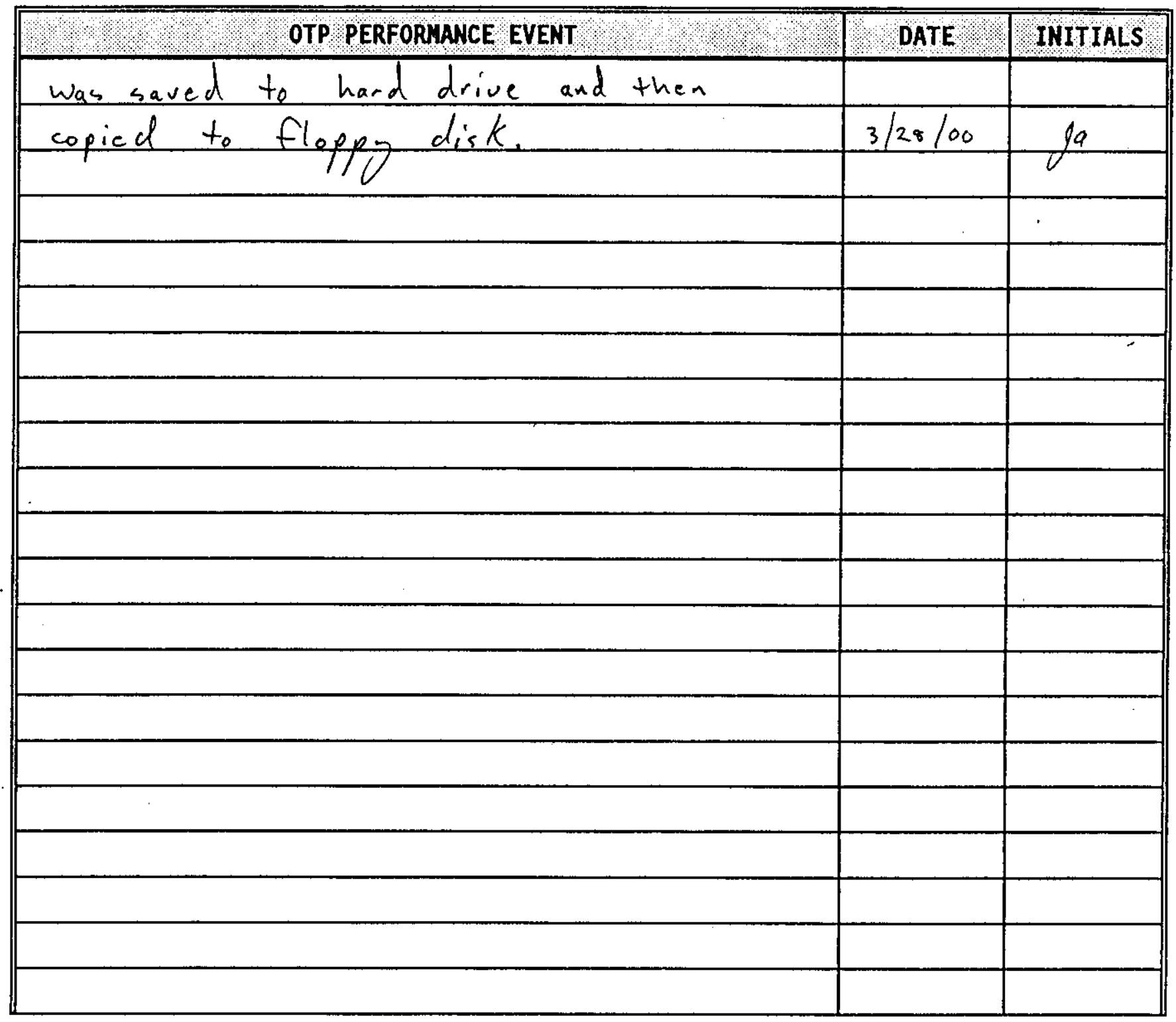


OPERATIONAL TEST PROCEDURE EXCEPTION LOG

This page may be reproduced as necessary. Page 1 of 1

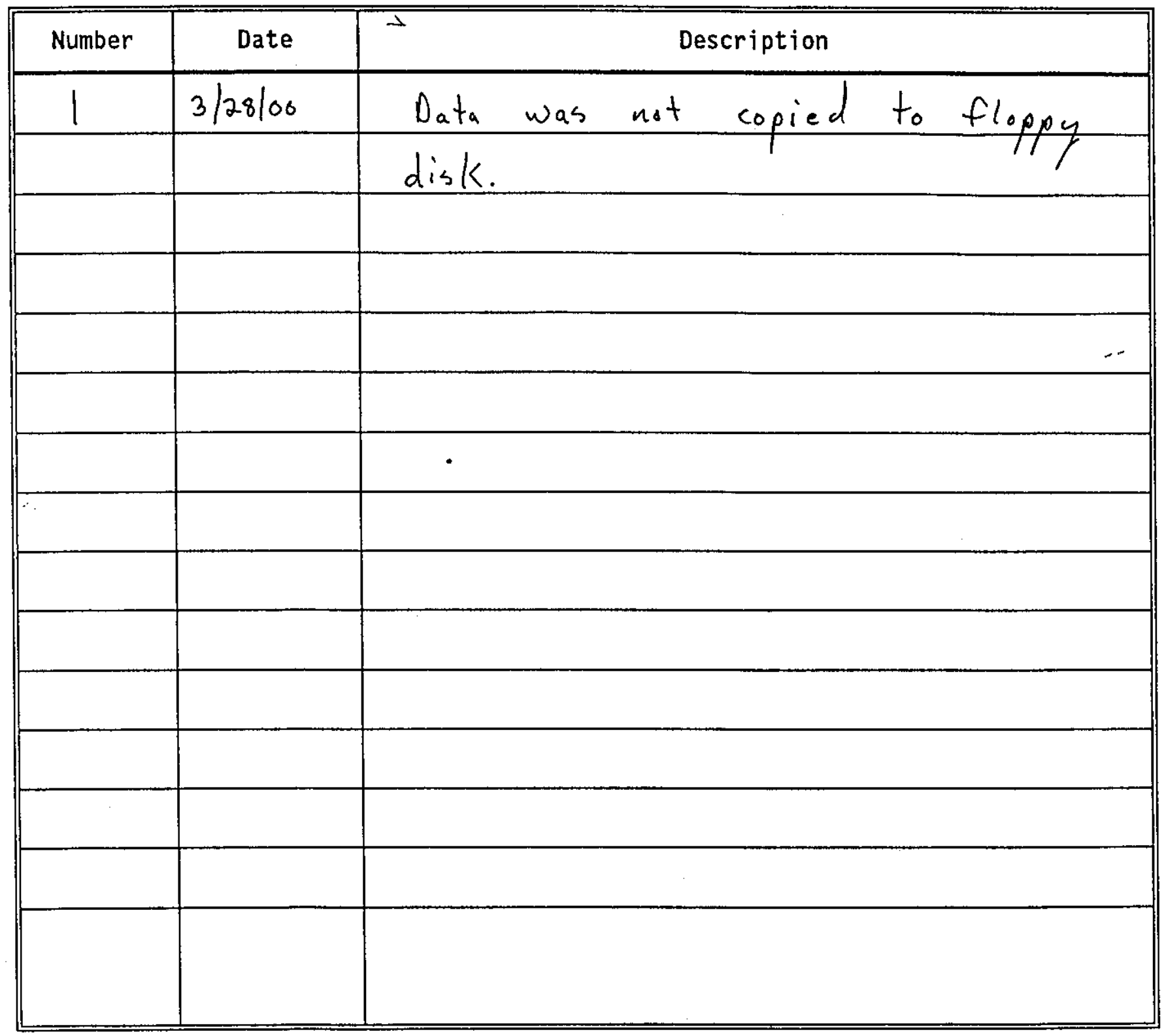




\section{OPERATIONAL TEST PROCEDURE EXCEPTION RECORD}

This page may be reproduced as necessary. Page 1 of 1

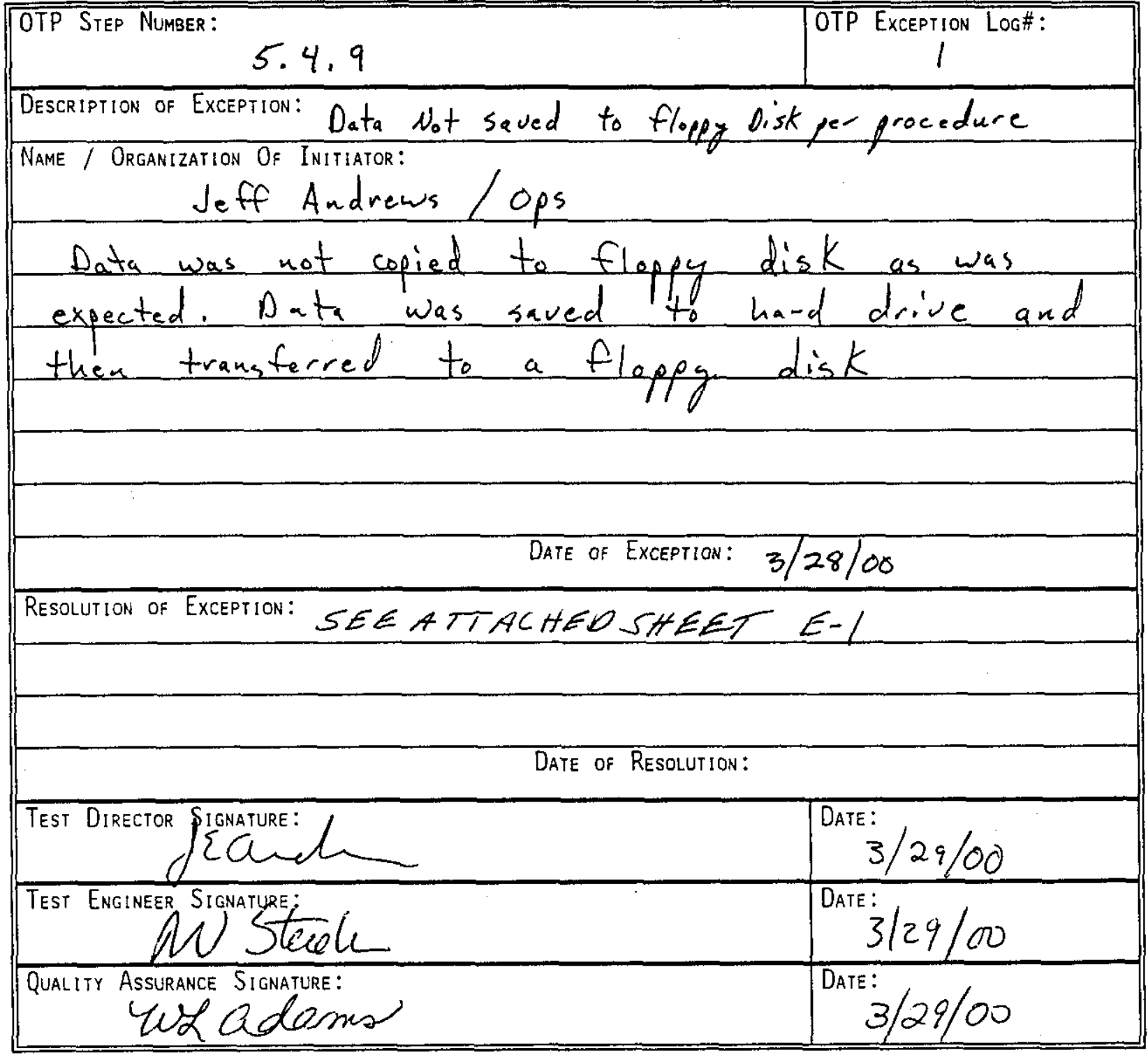

\begin{tabular}{|c|c|c|c|c|}
\hline CON & Documet No & $\begin{array}{c}\text { RevMod } \\
\text { A-4. }\end{array}$ & $03 / 21 / 2000$ & 310 \\
\hline
\end{tabular}




\section{PROCEDURE SIGNATURE SHEET}
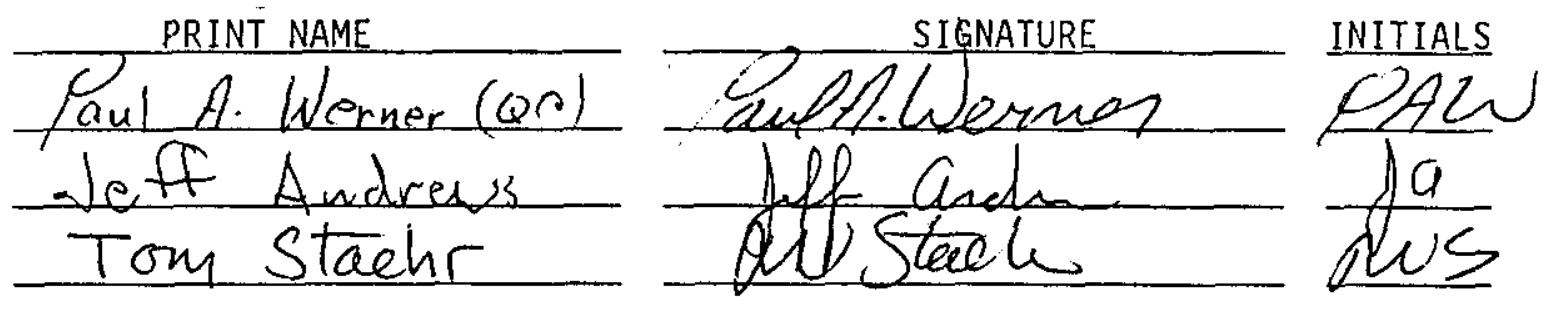

A1-35

RPP.6133, Rev 0 


\begin{tabular}{lr} 
Profiler & \multicolumn{1}{l}{ \#50 } \\
3/28/10 & $10: 00$ \\
odepth & 0.00 \\
Clarity & 10720 \\
Sta.0 & 10912 \\
Sta.1 & 10720 \\
Sta.2 & 1752 \\
Sta.3 & 283 \\
Sta.4 & 254 \\
Sta.5 & 171 \\
Sta.6 & 260 \\
Sta.7 & 257 \\
Sta.8 & 270 \\
Sta.9 & 211 \\
Sta.10 & 297 \\
Sta.11 & 310 \\
Sta.12 & 306 \\
Sta.13 & 237 \\
Sta.14 & 300 \\
Sta.15 & 260 \\
Sta.16 & 267 \\
Sta.17 & 247 \\
Sta.18 & 224 \\
Sta.19 & 224
\end{tabular}




\section{OTP-260-005 EXCEPTION \#1}

\section{Resolution of Exception. Discussion}

Test exception 1 identified that the SSP computer did not save the data to a floppy disk.

Step 5.4.9.3 of the test procedure detailed the keystrokes required on the SSP computer for the SSP software program to "Send to Disk". This portion of the test was to verify that the data from the SSP could be saved electronically. Initial interpretation was that the "Send to Disk" statement on the SSP menu referred to a floppy disk. The vendor software "Send to Disk" statement refers to the computer hard disk. The data can then be copied from the hard disk to a floppy disk and printed as per step 5.4 .10 of the test procedure. Therefore the system was accepted and no retest was required. 